\title{
THE LAST PRINCES OF THE HOUSE OF COLLALTO E SAN SALVATORE IN MORAVIA
}

\author{
JAN K O U M A R
}

\begin{abstract}
KOUMAR, Jan. The Last Princes of the House of Collalto e San Salvatore in Moravia. Historický časopis, 2019, 67, 4, pp. 633-657, Bratislava.

This study deals with life and activities of the last four Princes Collalto e San Salvatore who owned the Moravian family estates between 1854 and 1945. On the basis of preserved archive materials, it provides a biographical overview of their lives, family situation and of their activities connected with Moravian estates during the end of Austria-Hungary, First Czechoslovak Republic and post-war Czechoslovakia. Among these four Collaltos, Emanuel Josef (1854-1924) is the central figure, though, to understand the stagnation of the House of Collalto under its four last Princes, attention is also paid to Emanuel's father Eduard and his two successors: Manfred and Octavian.

Key words: House of Collalto. 19th century Moravian Aristocracy. First Czechoslovak Land Reform. Collalto fideicommissum.
\end{abstract}

DOI: https://doi.org/10.31577/histcaso.2019.67.4.3

\section{Introduction}

Among the many aristocratic land owners in Moravia at the end of 19th century the members of the House of Collalto e San Salvatore are definitely not the best-known ones. The House could certainly boast some renowned names from the past: Rambaldo XII the Great (1579-1630): field marshal during the Thirty Year's War, the conqueror of Mantua and the founder of the Moravian fideicommissum $;^{1}$ Antonio Rambaldo (1681-1740): a generous benefactor of fine arts in Moravia who hosted Charles VI twice in his castle at Brtnice and had the whole event painted for future generations; ${ }^{2}$ or an art-loving keen builder Odoardo III, who was elevated to the dignity of Austrian Prince (Fürst) in 1822 by Francis I. ${ }^{3}$ However, the second half of the 19 th and the beginning of the 20th century,

1 PASSOLUNGHI, Angelo. I Collalto: linee, documenti, genealogie per una storia del casato. Villorba: B\&M edizioni, 1987, p. 89-91. Rambaldo's Last Will: Ibidum, p. 149-157.

2 VÁCHA, Štěpán, et al. Karel VI. a Alžběta Kristýna. Česká korunovace 1723. (Charles VI and Elizabath Christina. The Czech coronation of 1723). Praha: Paseka, 2009. ISBN 9788074320026.

3 PASSOLUNGHI, ref.1, p. 180-182. 
caught the Austrian Collaltos in a state of stagnation: the name of the House cannot be found in connection with the high politics, fine arts, high-society activities or Moravian business. Certainly, the historic period is partly to blame. For the Austrian aristocracy, the second half of the 19th century was not the best time. After 1848, they lost their patrimonial rights and changed from Lords to mere landowners, hence the period meant an identity crisis, ${ }^{4}$ which was not helped by the situation in Austria and Czechoslovakia after the First World War. Though, while other noble Houses of the second half of the 19th century (such as the Belcredis, Auerspergs or Dalbergs) were great builders, politicians and businessmen, the House of Collalto stood aside from all these activities.

That may be the reason why, up to now, the last owners of the vast Moravian properties have not been paid much popular attention. There were four of them: Eduard, the 3rd Prince of Collalto (1810-1862) and his son Emanuel, the 4th Prince (1854-1924) were of one family branch, Manfred, the 5th Prince (1870-1940), the successor of the childless Emanuel and Manfred's son Octavian (1906-1973), who moved to Italy after 1945 when his Czechoslovak property was confiscated, were of the other. Out of these four names Emanuel Collalto is by far the most interesting. Not due to his great achievements or unforgettable importance - in fact, it was he, who presided over the above-mentioned stagnation - but due to his 62 years as head of the family. While Eduard held the main Moravian estates only for 8 years, Manfred for 16 and Octavian for only 5 years, Emanuel was by far the most important member of the Austrian branch of the House at the dazzling fin de siècle, during the war and at the stormy beginnings of Czechoslovakia.

The ambition of this text is to offer a closer look at life and activities of these four members of the House of Collalto e San Salvatore in Moravia. Even though their possessions were in Moravia and seemingly belong to the local history, the family had Italian roots (and in Italy living members), marriage ties with Hungarian families and lots of places of interests connected with the name Collalto are preserved in Austria: ${ }^{5}$ for this reason, the article is written in the internationally more accessible English instead of the more usual Slovak, Czech or German. ${ }^{6}$

4 MAYERHOFER, Ernst. Handbuch für den politischen Verwaltungsdienst der in Reichsrate vertretenen Königeiche und Länder mit besonderer Berücksichtigung der diesen Ländern gemainsamen Gesetze und Verordnungen. Wien 1901, p. 151-154 and ŽUPANIČ, Jan. Rakouská šlechta na prahu nové doby. (The Austrian aristocracy on the threshold of a new age). In KNOZ, Tomáš - DVOŘÁK, Jan (eds.). Šlechta v proměnách věkư. Brno: Matice moravská, 2011, p. 194-207. ISBN 9788086488714.

5 KOUMAR, Jan. Vídeňská a moravská sídla Emanuela Josefa 4. knížete Collalto e San Salvatore. (The Viennese and Moravian seats of Emanuel Joseph, 4th Prince of Collalto e San Salvatore.). In Historica, 2019, 10, 1, p. 33-47. ISSN 1803-7550.

6 Similarly, to draw attention of the professionals to the Collalto archive documents the authors 
Fortunately, to fulfil the above-mentioned immodest target the text can be grounded in the numerous archive documents preserved in the Moravian Land Archive in Brno (MZA), above all, the collections G169 - Collalto Family Archive and F19 - Central Administration of Collalto Estates, together with the other documents from local archives and published books. Priceless sources of the information about the family and nature of the last Collaltos are provided by two German-written unpublished memoirs by Marie Therese Collalto: Von unseren Vorfahren (From our Ancestors) ${ }^{7}$ and Erlebtes und Geschautes (Experienced and Witnessed $)^{8}$ - kept in the MZA Brno and one published Czech family chronicle Kořeny věků (Roots of Ages) by Václav Flesar. ${ }^{9}$ Throughout this text only the necessary attention is paid to the higher policy and the situation in which the last Collaltos lived. It may present a certain limit of this article, yet, its main target is to concentrate on the little-known biographical features not to digress to the undoubtedly well-known - wider context.

\section{House of Collalto and their Moravian estates}

The House of Collalto (from Italian colle alto = high hill) was of an old Lombardian origin. ${ }^{10}$ Legendarily it begins with the man called Rambaldo who was given the first family privileges by kings Adalbert and Berengar, ${ }^{11}$ the first indisputable documents come from 958 when the Collaltos gained their feud in Trier March just in the neighbourhood of the Venetian Republic. Around 1300, under Rambaldo VIII. castle of San Salvatore was built, and the power centre - originally located in Castelo di Collalto - was gradually moved there. ${ }^{12}$ The founder of the Austrian family branch was Marco Carlo, an ambassador of the Holy Roman Emperor Charles IV at the papal court of Innocent IV. Yet, the greatest attention and honour belongs to the above-mentioned Rambaldo XIII as the founder of a

of the exhibition catalogue "Z Trevisa do Brtnice / Da Treviso a Brtnice" wrote their studies in both Czech and Italian. See ELBEL, Petr - SCHMIDT, Ondřej - BÁRTA, Stanislav. Z Trevisa do Brtnice. Př́běhy šlechtického rodu Collalto ukryté v českých archivech. (From Treviso to *Brtnice. Stories of the Collalto aristocratic family hidden in the Czech archives). Brno: Masarykova Universita. 2019. ISBN 9788021091825

7 Moravský zemský archív (hereinafter: MZA) Brno, fund G169 - Rodinný archív Collaltů (hereinafter: G169), carton (hereinafter: c.) 320, inventory number (further on: i. n.) 421.

8 MZA Brno, G169, c. 308, i. n. 233.

9 FLESAR, Václav. Kořeny věků. Kronika rodu Flesarů psaná v letech 1423-1923. (Roots of the ages. A chronicle of the Flesar family, 1423-1923). Jimramov: V. Flesar, 2015. ISBN 9788026088332.

10 PASSOLUNGHI, ref. 1, p. 33.

11 For the privileges see: PASSOLUNGHI, ref. 1, p. 113-114.

12 PASSOLUNGHI, ref. 1, p. 51-54. 
vast domain in Moravia. ${ }^{13}$ He bought manors in Moravia - confiscated after the Bohemian Revolt - from Ferdinand II and united them according to his Last Will in a fideicommissum which subsequently stayed under the Collalto's control until 1945. ${ }^{14}$ During that time the Austrian branch of the House of Collalto was elevated from Counts to Princes ${ }^{15}$ with the "High Serene" (Durchlaucht) predicate. In July 1707 they gained the Bohemian inkolat and their possession grew into the 10th largest in Moravia. ${ }^{16}$

The whole Collalto domain was situated in three separated clusters in the west and south-west of Moravia. The largest manor Brtnice (Pirnitz) ${ }^{17}$ bought for 110,000 fl. by Rambaldo XIII used to be its centre, the Central Directorate Office resided in its castle (in the east-west oriented wing between the first and second courts). At the end of the 19th century the whole manor was 6,638 ha large, with three chateaux: the largest and oldest castle in Brtnice, smaller residences in Kněžice (Knieschitz) and Jestřebí (Hasslitz). Due to its altitude the main economic resource of the manor was not agriculture but forestry; in its village Opatov a glass factory was established by Anton Octavian Collalto, it was named after his wife Caroline: Karlín (Karolienthal), another important economic source was the farmyard in Heratlice (Heraltitz). Eduard 1st Prince of Collalto founded a

13 KAZLEPKA, Zdeněk. Ostrov italského vkusu. Umělecký mecenát Antonia Rambalda hraběte z Collalto a San Salvatore mezi Itálií, Vidní a Moravou v první polovině 18. století. (An island of Italian taste. The artistic patronage of Antonio Rambaldo Counnt of Collalto and San Salvatore between Italy, Vienna and and Moravia in the first half of the 18th century). Brno: Barrister Principal, 2011, p. 30-35. ISBN 9788070272466..

14 There were 17 holders of the Moravian fideicommissum: 1/ Its founder: Rambaldo XIII the Great (1579-1631) 2/Claudius III. (1627-1661), 3/ Rambaldo Hanibal I. (1661) a child who died in the age of one year, 4/ Antonio Francesco (1630-1696) 5/ Leopold Rambaldo (1674-1707) the last of his family branch. In 1707 6/ Vinciguerra V. (1649-1719) from the younger Italian family branch inherited Moravian estates and established a new Moravian line 7/ Antonio Rambaldo (1671-1740), 8/ Thomas Vinciguerra (1710-1768), who expanded the family possessions with Uherčice, Písečné and allodial Okř́ršky. 9/ Johan Nepomuceno (1772) a child who died in the young age, 10/ Francis Augustin II. (1714-1779), the last of his family branch. The younger Italian line had to take over the Moravian estates again. 11/ Antonio Octavian (1719-1793), 12/ Eduard III., 1st prince (1747-1833), 13/Anton Octavian, 2nd Prince (1791-1854). Finally, there are the last four Princes, this text deals with: 14/ Eduard IV, 3rd Prince (1810-1862), 15/ Emanuel 4th Prince (1854-1924), who was the last of his branch. 16/ Manfred, 5th Prince (1870-1940) and 17/ Octavian (1905-1973).

15 Principe dell' Impero Austriaco. The title of Prince was inherited according to the rules of primogeniture, the other family branches used the title "Count" (Graf). See: PASSOLUNGHI, ref. 1 , p. 180-182.

16 SANDGRUBER, Roman. Österreichische agrarstatistik 1750-1918. In HOFFMANN, Alfred - MATIS, Herbert (eds.). Wirtschafts- und Sozialstatistik Österreich-Ungarns, Part 2. Wien 1978

17 Throughout the text, I use the current Czech village and town names. When first mentioned, their German translations used at the end of 19 th century are provided. 
small textile factory in Brtnice in 1801, but it did not exist for long, after only ten years it went out of business again, due to severe competition from the French textile industry. ${ }^{18}$ Geographically connected to Brtnice (but separately administered) was the allodial manor Okřřšky (Okřiško) with Pokojovice (Pokojowitz) bought by Thomas Vinciguerra in 1741.

The second cluster was situated north-east of Brtnice: it consisted of a smaller manor Černá (Tscherna) and Německý Rudolec (Deutsch Rudoletz) of the area of 1,702 ha, with two little chateaux and the main forest districts. This manor represented the highest point of the Collalto domain: the summit of Arnolecká Mountain touches the altitude of $693 \mathrm{~m} \cdot{ }^{19}$ The third cluster was located south-east of the centre in Brtnice and unlike the previous manor, it had a much warmer climate more favourable to agriculture. It was created by two formerly separate manors: Uherčice (Ungarschitz) and Písečné (Piessling) with Slavětín (Slavaten) and was bought and connected to the fideicommissum in 1768 under Thomas Vinciguerra. Uherčice had the area of $1,621.43 \mathrm{ha}^{20}$ and a magnificent Renaissance chateau modified in Baroque and Neo-Classical periods. Due to its proximity to Vienna and its mild climate, it attracted the Collaltos as a place for summer stays. Písečné, on the other hand, was a small (641.53 ha) agricultural manor, neighbouring with Uherčice on the west. ${ }^{21}$ In Nové Sady (Neustift) on the hill above Písečné, before 1823, a sepulchre of the princely line of Austrian Collaltos was built and used until $1886 .{ }^{22}$ In 1904, the whole extent of the Moravian fideicommissum was 10,827 ha.

In certain historical periods the Collaltos owned various other estates in Moravia and in Lower Austria: such as Veveří Castle near Brno in the last quarter of the 17th century, manor Braunsdorf in Austria between 1806 and 1856, or Bohemian manor Liběchov (Liboc) between $1872-1878 .{ }^{23}$ But besides these

18 The whole manor needed an economic base, which was created mainly by the farms and courtyards. In 1900 there were 13 courtyards, 2 starch plants, 1 brewery, 2 distilleries, 2 mills and 2 brickyards, a lime works, 3 sawmills and 8 forest districts.

19 Its economic base must be mentioned again: 6 courtyards, distillery, a starch plant and a brickyard together with 3 forest districts.

20 With a distillery, a lime works, a sawmill, a mill and a brickyard and 3 forest districts.

21 There was one distillery, a sawmill, a mill and 2 forest districts.

22 The sepulchre is situated in the cellar of a former bell-tower. Nine burials were made between 1827 and 1886. Cecilia (24. 1. 1827), Eduard 1st Prince (5. 2. 1833), Rambald Antonio (4. 10. 1840), Marie Caroline (18. 8. 1842), Anton Octavian 2nd Prince (27. 11. 1854), Johan (3. 12. 1860), Eduard 3rd Prince (29. 3. 1862), Caroline (24. 4. 1872) and Caroline (26. 6. 1886). (MZA Brno, G169, c. 378, i. n. 205).

23 Liběchov (Liboc) is especially interesting. The curators of the underaged Prince Emanuel bought this estate near Mělník from A. L. Veith, who got deep in debts. The local chateau was well-known to patriotic Czechs for frequent stays of Palacký, Riegr, Velc or Bolzano. The reason for such a purchase is not known, Emanuel's curators had to know it was far from 
temporarily held estates, there was one place in Austria which kept being within the family possession since Rambaldo the Great: a majorate palace on the Vienna square Am Hof. The palace built on the walls of the old Babenberg fortress was rebuilt and extended several times. Until now, it remains a remarkable place for visitors to Vienna: with its baroque façade and the memorial plague reminding tourists of the first public musical performance in Vienna by Mozart and his sister Nanerl in 1762. Later, the new wings in the direction of Parisergasse and Schulhof were added and since the time of the first Prince Eduard the space in the ground floor were rented out to shops. ${ }^{24}$ The same Eduard also importantly rebuilt the house as same as the chateaus in Uherčice and Brtnice. As far as artistic, architectural and political achievements are discussed, he was to be the last great man of the House of Collalto for almost a century. Under his son, Anton Octavian the turning year 1848 came and brought the above-mentioned political changes and the beginning of stagnation of the Collalto family.

\section{The short reign of the third Prince: Eduard Collalto}

But let us start with Anton's son. Eduard Octavian IV., future 3rd Prince of Collalto e San Salvatore, was born on the 17th October 1810 in Vienna as Anton's first son with his wife Caroline née Apponyi de Nagy-Appony. Caroline, known as Lotti, was a renowned Hungarian beauty. She was long remembered in the family for one of the Viennese Court Balls where she was introduced to the King of Saxony. The King was so deeply captivated by her beautiful curly hair he exclaimed: "My kingdom for one of your curls Princess!" 25 Anton Octavian, on the other hand, was well-known for his lack of sociability: throughout his whole life he had problems with the German language and the family called him "un Orso" (a Bear) for his fondness for solitude, seriousness and for his melancholic nature ${ }^{26}$ Eduard was a first-born son, though, the couple were to have three more children: two years after Eduard's birth, his first sister Cecilia was born, second sister Caroline came into the world in 1818, but between them in 1816 the younger brother Alfons Giuseppe saw the first light of this world. There, with two brothers, the family branch splits. While the older Eduard inherited the title

the traditional Moravian domain of the House of Collalto, also the whole estate was not very profitable. Besides the vineyards there was not much to gain from it. Whatever the reason for its purchase, as soon as Prince Emanuel came of age (1878), he sold Liběchov to Nenig von Armin. (MZA Brno, G169, c. 453-457).

24 For more about history of the palace see: Günther BUCHINGER, Paul MITCHELL, Doris SCHÖN, Das Palais Collalto. Vom Herzogshof und Judenhaus zum Adelspalast. In Österreichische Zeitschrift für Kunst und Denkmalpflege, 2002, volume 56, issue 4, p. 402-419.

25 COLlaltO, Marie Therese. Von unseren Vorfahren, MZA Brno, G169, c. 320, i. n. 441, p. 4 26 Ibidem, p. 6. 
of Austrian Prince and the whole Moravian fideicommissum, the younger brother Alfons gained the Italian estates with San Salvatore, Credazzo, Rey and Musestre after the death of Vinciguerra VIII in 1844.

From 1818, Eduard attended Normal Hauptschule in Vienna, later he became a student at the then reputable Grammar School in Jihlava (Iglau), ${ }^{27}$ the most important city near the centre of Collalto's estates: Brtnice. The family usually spent their summers in Brtnice while in winters they were either in their Viennese Am-Hof palace or in Italian San Salvatore, which had a much more pleasant climate than the harsh Moravian weather. ${ }^{28}$ At the age of 24, Eduard married a 20-year-old girl: Caroline Apponyi, the namesake of his mother, but also his cousin. Caroline was the only child of Josef Apponyi, the third of four brothers - of whom the first born was the well-known Hungarian chancellor György Apponyi de Nagy-Appony - and was a highly educated, art-loving woman who brought Eduard a significant dowry. Their wedding took place in the Am Hof Church, right next to the Collalto Palace on 16th November $1834 .{ }^{29}$ After the wedding the young couple used to spend their summers in Uherčice chateau, while Eduard's parents lived in Brtnice and were often visited there by their daughters: Cecilie, wedded conveniently to Marquise and Count Friedrich August Piatti and Caroline, who married Prince Ferdinand Solms Hohensolms-Lich. The second mentioned couple met in Brtnice, where the young Hussar officer von Solms-Lich fell in love with young Caroline. Eduard's younger brother Alfons married Princess Ida Colloredo-Mansfeld and the couple arranged their summer residence is the small chateau at Kněžice (Knieschitz) near Brtnice. ${ }^{30}$

Eduard's marriage did not seem to be a happy one. His wife's mother, Tereze Pejacsevich suffered from a vaguely specified mental disease in her old age and unfortunately the same problems became a curse of her daughter. The life with a nervous spouse was a difficult one and was not helped at all by their family situation. The couple had three children during their first six years together: the first child Maria Caroline came a year after their wedding, the second child, a daughter Juliette, was born in 1838 and then finally a son and a Prince-ToBe: Rambaldo Anton was born in 1839. However, young Rambaldo died at the age of only 1 year on the 4th October 1840 and two years later the dead body

27 MZA Brno, G169, c. 370, i. n. 195.

28 Brtnice (Pirnitz) is located in the hilly cold plateau of the Bohemian-Moravian Highlands at the altitude of $543 \mathrm{~m}$. When Eduard's grand-mother came to the Moravian estates for the first time and was asked how she liked its climate, she described it as: "Eight months of cold and four months of not warm weather." (COLLALTO, ref. 22, p. 1).

29 Matrikula online: Wien, RC Erzdiözese (östl. Niederösterreich und Wien) 01., Am Hof, Trauungsbuch, 02-04, p. 125.

30 COLLALTO, ref. 22, p. 8. 
of his sister Marie followed him to the family sepulchre in Nové sady (Neustift). ${ }^{31}$ At the time of Eduard's grief for his daughter, his younger brother Alfons's son Octavian was born (5th May 1842). Since Eduard's little son had died, the child was considered the heir and the saviour of the family name, that is why he was nicknamed Octavian Salvatore. Even though the child was born unusually small and weak, also in spite of his overly strict upbringing, the boy was slowly growing up into a strong man who became a beloved grandchild of the old Prince Anton. ${ }^{32}$ Supposedly, Eduard was not happy about the family development. A partial reward for his unsatisfying family life may have been the fact that he started administrating the whole Collalto estate in Moravia and became the factual head of the family after his father was hit by a stroke and could hardly walk. The disease made the old Prince Anton more and more childlike; he began losing his memory and kept repeating the same stories which usually started with: "When I was still a young handsome Toni... "33

Unlike his nervous wife, Eduard was a good-natured humorous man, who liked telling jokes and whose liveliness and cheerfulness was well-known in the family. The Chronicle of the Flesars ${ }^{34}$ informs us about his affair with Francesca Flesar. She began working as a maid in Německý Rudolec castle as a 15-year-old girl in 1842 and Eduard, emotionally weakened after his son's and daughter's deaths and probably unable to find the consolation he wanted from his wife, fell in love with her around 1846. The affaire was not anything unusual by the standards of an Italian aristocratic family of the time: after all, Eduard's uncle Johan, the younger brother of Anton Octavian, died without a legitimate descendant and bequeathed quite an important part of his art collection to his illegitimate children, which put the valuable artistic collection created by the 1st Prince Eduard out of the family's reach.

The world in the 1840s was out of balance: despite the technical and social changes, the institutional consequences of these changes were modest at the best..$^{35}$ Therefore, it was no wonder that the revolutionary year 1848 threw

31 MZA, G169, c. 378, i. n. 205.

32 COLLALTO, ref. 22, p. 11.

33 Ibidem.

34 The chronicle has been written since 1423, entries written between 1423-1923 were published in 2015 (FLESAR, ref. 6). The last part of the chronicle was written by Francesca and her son Maurizio. The Chronicle suffers from some shortcomings typical for such a sort of historical sources: it was written by servants at the Collalto estates, and its purpose was not to document high politics and aristocratic life but the life of the Flesar family. The published part was also edited twice (for the first time by its last author Maurizio, who retyped the original handwritten old entries, and for the second time by the author of the published part). While the original was lost in France after 1947, the preserved text is one of the retyped copies Maurizio made.

35 HOBSBAWM, Eric. The Age of Revolution. NY: Random House, 1996, p. 303. ISBN 
Vienna into such a storm that the city became dangerous for the Emperor, and not only for him. ${ }^{36}$ Eduard Collalto e San Salvatore as the emperor's real chamberlain (wirklicher Kämmerer) ${ }^{37}$ was in Vienna quite often. Besides the residential majorate house on Am Hof (No. 420), he and his family often stayed in a new house at Jägerzeil 61 just a few steps from the Prater, also the house outside the city walls in front of Schottentor (No. 535) was sometimes used for summer stays. However, when the stormy events began to be unsafe, Eduard left for his Moravian estates. The end of the revolution was the beginning of evolution, ${ }^{38}$ though for the Collaltos, it meant mainly a big change in administration of their estates, since the revolution overturned traditions, finishing vestiges of patrimonial rules and the dominance of nobility in the country.

Eduard's father, Prince Anton died on 23rd November 1854, three days later his body was buried in the family sepulchre, and Eduard officially became the 4th Prince Collalto e San Salvatore. He had been in charge of the estates for many years, in fact it was he who ordered the reconstruction of Brtnice castle, during which a new wing on the second castle court was built. ${ }^{39}$ But the same year gave him a different kind of satisfaction he was long looking for. After 18 years of their marriage Eduard's wife Caroline got pregnant again and on Christmas Eve 1854 their second son was born in Uherčcice. The baptism ceremony was held the next day in Vratěnín (Frattig) the child was given a name Emanuel Joseph. ${ }^{40}$ A long-desired son in Eduard's family definitely meant an undesired change for Alfons's plans with his own children. Young Emanuel was strong, easily survived the childhood illnesses and prospered well, thus it seemed the sad story with little Rambaldo was not going to be repeated. The disappointment can be seen in the family memoires of Alfons's grand-daughter Marie Therese (Von unseren Vorfahren): while Eduard is described there as a cheerful man and attention is paid to Alfons's family, Eduard's children's names are only briefly

0679772537.

36 Other big cities of the Monarchy were in the fire of revolution too, of course. But neither Prague nor Budapest had the revolutionary character of Vienna in 1848 (TAYLOR, A. J. P. The Habsburg Monarchy 1808-1918. London: Penguin Books, 1990, p. 65. ISBN 9780140134988).

37 Only aristocrats of "pure" lineage could be appointed to such an office. 16 aristocratic descendants had to be documented before. (see UNOWSKY, Daniel. Reasserting Empire. Habsburg Imperial Celebrations after the Revolutions on 1848-1849. In BUCUR, Maria WINGFIELD, Nancy M. Staging the Past. The politics of Commemoration in the Habsburg Central Europe 1848 to the Present. West Lafayette: Purdue University Press, 2001. ISBN 9781557531612).

38 DEAK, John. Forging a Multinational State. State Making in Imperial Austria from the Enlightenment to the First World War. California: Stanford University Press, 2015, p. 106. ISBN 9780804795579.

39 In 1842, the master builder was Jan Rathausky from Jihlava (Iglau).

40 MZA, E67 Registry Znojmo, i. n. 14850 Birth Registry Vratěnín 1821-1859. 
remembered and no closer information about them is provided..$^{41}$ But Emanuel was not the only victory Eduard could inscribe after years of an unsuccessful family life. In the meantime, his affair with his chambermaid Francesca continued, she got pregnant and on 18th September 1859 Eduard's illegitimate son Maurizio was born. Two baptisms of the new-born son took place: the first one at the parish church in Bohdalov (Bochdalau), and the second one in Černá chateau, with the participation of godparents Moritz von Dietrichstein and Alexandra Mensdorff. ${ }^{42}$ Even though Maurizio was not legitimate, his future was prepaid by his godparents as well as by Eduard himself. Till the end of his life he used his double surname Collalto-Flesar.

However, Eduard was not to enjoy his sons for long. In 1861 he married off his daughter Juliette to Karl Count from Walderdorff: between 1862-1881, their marriage was to bring twelve children. The same year brought him a hereditary membership in the Austrian House of Lords (Herrenhaus). The members of this institution, created by the February Patent, were appointed - unlike the elected members of the House of Deputies - the House of Collalto was among the 16 other princely Houses awarded this honour. The House of Lords met for the first time on 29th April 1861, though Eduard did not take part: he apologized due to illness. ${ }^{43} \mathrm{Had}$ Eduard Collalto planned important political acts or career, his time was too short to put it into practice. In late 1861 he started having heart problems which he tried to cure at the best doctors in Vienna, but all treatment served to no purpose, because on 24th March 1862 Eduard Collalto e San Salvatore died of a heart attack at the age of 52 .

\section{Demimonde of Emanuel Collalto}

Eduard's 8 year old son Emanuel became the inheritor of the Moravian estates and 4th Prince. In the noble society, Eduard's death provoked a discussion about the kinship between Houses of Collalto and of Hohenzollern, ${ }^{44}$ as well as speculation about the future of the Austrian and Moravian estates if Emanuel died. ${ }^{45}$ Eduard's body was buried in the family sepulchre at Nové Sady next to his father

41 COLLALTO, ref. 22.

42 The Birth Certificate of Maurizio Flesar in: FLESAR, ref. 6, p. 642.

43 LANJUS, Friedrich. Die erbliche Reichsratswürde in Österreich. Schloß Haindorf am Kamp 1939, p. 84.

44 It was of a legendary origin, yet the founder of the Moravian fideicommissum (Rambaldo XIII) appointed the members of the Hohenzollern family to inherit the Collalto possessions in case of the extinction of the House.

45 ANNO Zeitungen - Austrian Newspapers Online: http://anno.onb.ac.at/ (furthermore ANNO), Klagenfurter Zeitung 16. 4. 1862, p. 2. 
and his short membership in the House of Lords was mentioned in the obituary given by Karl Auersperg at the House's next meeting. Because of Emanuel's age, his uncle Alfons was appointed the legal guardian, while Count Widmann and a Viennese lawyer Dr. Zeiner became the curators of the fideicommissum. However, the real administrator and Emanuel's protector was the Princess Widow, Caroline. She was an energetic woman, but - as previously mentioned - nervous and very often in severe rage attacks. Caroline's lifestyle was not influenced by Eduard's death too much, she still spent her winters in the Am Hof palace or at the residences of her father Josef Apponyi in Kalksburg and Voslau. After her mother's death she also bought a magnificent villa at Hohe Warte 52 in Heiligenstadt, ${ }^{46}$ where she - the Sternkreuz-Ordensdame - led quite busy social life, her letters also provide the evidence of her casual visits in Velké Oponice $(\mathrm{Na}$ gy-Appony) the traditional seat of her family. ${ }^{47}$

While the guardianship of Alfons Octavian was exaggeratedly strict, Ca-

roline was raian opposite manhim to feel responendowed with poey, therefore her program was to one of the most althe House histoclash of their two young prince's not a lucky one. It problems, thouformed Emanuel's view of the world. life Emanuel 4th San Salvatore was ous on the one vagant on the lifestyle surfaced First World War, ation of the young lic, he was gambClub, eating at Sa-

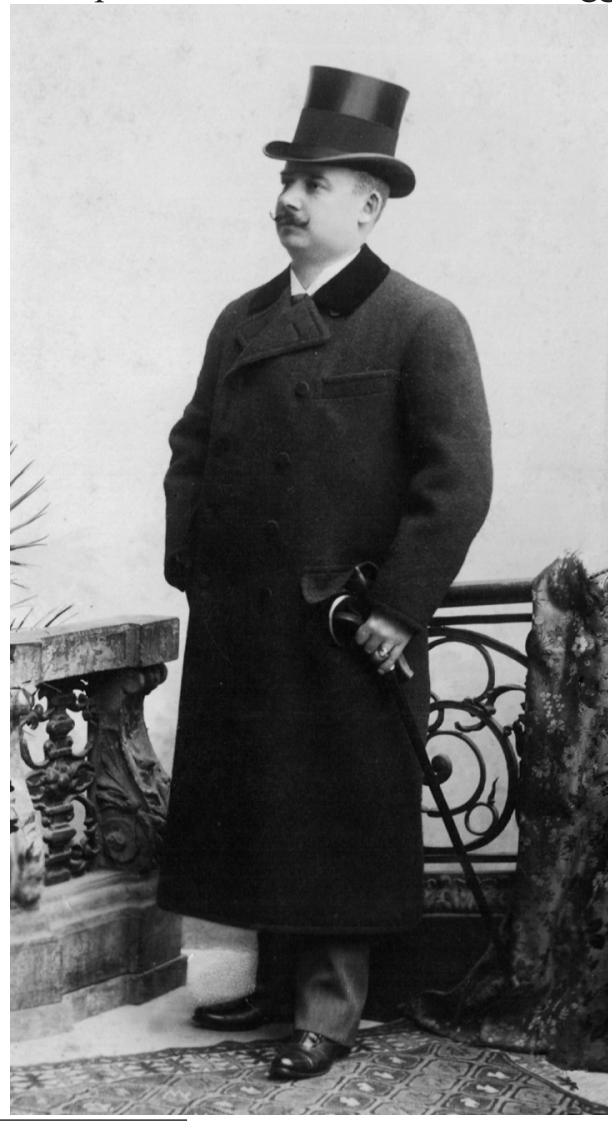
sing her son in ner. She taught sible for the less ssession and mongenerous charity make Emanuel truistic figures in ry. However, this approaches to the upbringing was brought no visible gh, it definitely lifestyle and his Throughout his Prince Collalto e incredibly generhand, and extraother. His lavish the most after the when in the situAustrian Republing in the Jockey cher's and being

46 Nowadays the Egyptian Embassy

47 MZA Brno, G169, c. 374, i. n. 203/IV and c.375. 
driven around Vienna in a car, while the members of his wider family hardly had money to pay their own servants. ${ }^{48}$ But as a child Emanuel naturally was not only under the influence of his two impressive guardians. He was going to school in Vienna, later to a Grammar School in Kalksburg and later he finished his studies in Italy. As far as we can judge from Emanuel's preserved school exercise-books, he was an average student: besides German and Italian he spoke French, wrote in Latin and Greek and in compliance with the then prevailing teaching methods, he kept rewriting long passages from Xenophon, Homer or Livy.

Emanuel's step-brother, Eduard's illegitimate son Maurizio, was meanwhile living with his mother in Rudolec castle, but in 1866 he began his studies in Vienna too and the two brothers seemed to find a way to each other. They met at Christmas dinners every year ${ }^{49}$ they also made friends and their friendship lasted till Emanuel's death in 1924. Maurizio often travelled with his brother and took part in his lavish lifestyle, but he married an ordinary village girl and kept returning to the simple life in Rudolec. ${ }^{50}$

When Emanuel came of age, he refused to follow the pattern of his parents' life and did not get married. It is uncertain whether his mother supported him in this decision or not - the archive materials keep silent about it. She still tended to spend her time in Uherčice, but also in her above-mentioned villa in Heiligenstadt, the fashionable suburb of Vienna spread on the hillsides of Kahlenberg. Her son, however, had his residence at first in a villa at Schönbrunner Hauptstrasse 125 in Meidling, ${ }^{51}$ but he sold it in 1880 to build a new Collalto palace of his own in the inner city. The Neo-Renaissance four-floor house with the address Rathausstrasse $21^{52}$ was built by Anton Adametz between 1880 and 1881 and contained marbled rooms, carved staircases and a small courtyard with a fountain. ${ }^{53}$ Emanuel Collalto occupied the first floor - the 500-square-metre area with

48 COLLALTO, Marie Therese, Erlebtes und Geschautes MZA Brno, G169, c. 308, i. n. 233, p. 288.

49 The dinners were held in Brtnice but also in the other Colllato castles (Černá). See: FLESAR, ref. 6 , p. $478,480,487,488$.

50 Compare with: FLESAR, ref. 6, p. 489-596.

51 MZA Brno, G169, c. 393, i. n. 250.

52 Due to the position on the corner of two streets the plans and accounts state two addresses: Rathausstrasse 21 and Universitätstrasse 9. The house still exists and with its Collalto coat of arms above the entrance gate it is still recognizable as a princely palace. It remains the only existing one of Emanuel's original four houses in Vienna (Schönbrunner Hauptstrasse 125; Rathausstrasse 21; Armbrustergasse 21; Eroicagasse 9). All the other houses were destroyed or rebuilt.

53 MZA Brno, F19 - Ústřední správa collaltovských statků (Central administration of the Collalto estates) (hereinafter: F19), c. 1305. 
a balcony, the other floors were rented, in the ground-floor a restaurant and a bookshop used to exist. ${ }^{54}$

Caroline died on 23rd June 1866 and was buried in the family sepulchre at Nové Sady ${ }^{55}$ alongside her husband and two children, nevertheless after her death Emanuel turned out not to be as keen on single life as it had seemed. He definitely had already had some affairs, after all, his contemporaries preferred affairs with prostitutes to the demonized onanism, ${ }^{56}$ but probably from 1879 - the year their first preserved letters are from ${ }^{57}$ - he started meeting a fiveyears-younger Miss Irma Büttner (1859-1931) and till his mother's death there was a romantic relationship between the two of them. For the 32-year-old Emanuel it was definitely the right time to get married, but he had kept his relationship secret, as Miss Irma was lowborn. Being a daughter of a Major Eduard Büttner who fell at Montebello in 1859 and of Ludowika von Büttner née Oth, Irma certainly enjoyed some dignity. However, it was far from being a part of the first society of the K. K. court. Morganatic marriages were not unknown at the end of the 19 th century, ${ }^{58}$ though, they were mostly connected with second-born sons, who were not expected to ensure the family future with a "pure blood" offspring. Emanuel - a head of the House of Collalto in Austria - was a different case.

Irma was undoubtedly a beautiful woman. Even Emanuel's wider family who did not grow fond of her at all, had to admit her certain style together with "something special", which seemed to attract Emanuel. But at the same time, they saw her as a simple woman with a complete lack of education and culture; she did not know how to behave in a noble society even after 50 years spent in the most brilliant environment. ${ }^{59}$ For the first time, Emanuel's inclination to what his grand-niece called the demimonde became evident: he was used to living in

54 See KOUMAR, ref. 5.

55 Haus-, Hof und Staatsarchiv (hereinafter: HHStA) Wien, SB Partezettelsammlung 16-51.

56 The relationship of an aristocrat with prostitutes can be nicely learned from the letters of Baron Johannes Nádherný. Even though he belonged to a lower layer of the noble society than Emanuel Collalto, the records of his sexual affairs with prostitutes in Prague inform us about the sexual life of a contemporary nobleman. Baron Nádherný died in 1913 of syphilis. For more see WAGNEROVÁ, Alena. Bol lásky prodejné: ze života Johannese Nádherného a jeho milostných družek. (Could love be bought: from the life of Johannes Nádherný and his romantic partners). Praha: Argo, 2013. ISBN 9788025708293.

57 MZA, G169, c. 393, i. n. 249.

58 The marriage of Vaclav Kounic with an actress can be taken as an example, along with Octavian Kinski who married a circus horse rider when he was 75 (BEZECNÝ, Zdeněk. Sňatky české šlechty ve druhé polovině 19. století. (Marriages of Czech noblement in the second half of the 19th century). In PETRBOK, Václav (ed.). Sex a tabu v české kultuře 19. století. Praha: Academia, 1999. ISBN 8020006850). 
the comfort and luxury of his class, though he kept being attracted to the lower classes and in some cases behaved as if there was no partition wall between him and them. Such behaviour could not certainly be accepted in the aristocratic Austro-Hungarian society. Emanuel knew his Irma would be an obstacle in obtaining any higher rank at the court, it was out of question she would take part in the court ceremonies and celebrations, such as the Hofball and Ball bei Hof, where roles were assigned according to the court rankings and privileges. ${ }^{60} \mathrm{He}$ was certainly aware of the possible problems with the future children and their legal demands on the family estates, however, all these problems seemed unimportant, Miss Irma turned out to be the love of his life.

The possible loss of political merit seemed the least important, Emanuel Collalto never took charge of the inherited membership in the House of Lords and he withdrew from all political activities. Even though Lanjus ${ }^{61}$ attributes this withdrawal to the political situation in Italy, where the unification movement weakened Austrian politics and after defeat in the war against Sardinia, Austria gave up its Italian state of Lombardy and lost influence in other Italian states, ${ }^{62}$ the truth lies in the nature of Prince Emanuel. He used the title of Honorary Knight of the Order of Malta - a traditional honorary title in the House of Collalto - but he never aspired to any higher dignity. Franz Josef reasserted his predicate Serene Highness (Durchlaucht) in July $1905^{63}$ and only one imperial audience happened during Emanuel's lifetime, in 1907. ${ }^{64}$ Even though he may have presented this withdrawal from the political affairs of the empire as a consequence of Austrian policy in Italy, in the wider context it resulted from his complicated nature. He liked leading the splendid life of a high-class aristocrats, in the noblest environment and the noblest European resorts, where he could discuss policy as a part of his small talks at breakfast, but where he never had to practice it. Prince Emanuel liked travelling. He used to rent two flats in Paris, ${ }^{65} \mathrm{a}$ villa in Switzerland, he was a frequent guest with his mother's family in Hunga-

60 Emanuel Collalto would not be the first aristocrat in a morganatic marriage. About the heir to throne Franz Ferdinand and his morganatic marriage with Sophie Chotek (later von Hohenberg) see: BESTENREINER, Erika. Franz Ferdinand und Sophie von Hohenberg: Verbotene Liebe am Kaiserhof. München: Piper Verlag, 2004. ISBN 9783492045148.

61 LANJUS, ref. 40, p. 54.

62 About Austria-Hungary's Campaign against Italy see: CORNWALL, Marc. The Undermining of Austria-Hungary. The Battle for Hearts and Minds. Palgrave: Macmillian, 2000, p. 74-256. ISBN 978134942240.

63 ANNO Sport und Salon 2. 9. 1905, p. 4. Reasserting the Durchlaucht predicate was nothing odd, at the same time it was reasserted by 17 other Houses (ANNO Wiener Zeitung. 26. 7. 1905, p. 3).

64 ANNO Das Vaterland 28. 1. 1907, p. 2.

65 MZA Brno, G169, c. 452, i. n. 480. 
ry and besides regular hunting seasons spent on his Moravian estates, in winter 1908, he made a hunting trip to African Djibouti. ${ }^{66}$ Political worries were the last thing he wanted to be occupied with.

What Emanuel probably feared more was the problems his future children would have - the Testament of the fideicommissum founder disqualified all children of a low-born wife from the inheritance - and he himself would have - morganatic marriage was to be a transgression of the fideicommissum regulations. The married couple met other members of the high society, ${ }^{67}$ but it is unlikely Irma had ever been presented as anything more than Emanuel's companion. They were engaged but a quick and secret wedding in a church next to their villa in Heiligenstadt, Vienna took place only after the fall of the Empire on 28th May 1919 when Emanuel - now with Czechoslovak citizenship - was safe from any loss of his properties due to his morganatic marriage. Even at the moment of Emanuel's death in 1924 the Neues Wiener Journal first informed about the death of a childless, unmarried prince and only the next issue brought the information about the very existence of Princess Irma in a correction to the previously stated obituary. ${ }^{68}$ The Salonblatt, the traditional paper of the Viennese aristocracy informed about Irma for the first time in September 1924, ${ }^{69}$ the biographer of the Collaltos, Angelo Passolunghi ignored her existence completely. ${ }^{70}$

The wider Collalto family saw their relationship as a mistake hence unsurprisingly, Irma became a symbol of Emanuel's inclination to the lower-classed people, his fondness and frequent contacts with Eduard's illegitimate son Maurizio and Emanuel's withdrawal from politics. Marie Therese, accused her of having a bad influence on Emanuel, ${ }^{71}$ even though it is disputable whether Irma was not more a consequence of his inclinations than their cause. One way or another, their relationships and later marriage remained childless, which only shed brighter light on Emanuel's extravagant lifestyle and made him increasingly unpopular with the rest of the family. By that time, he spent less time in his new Viennese residence at Rathausstrasse, but resided more and more in his magnificent villa in Heiligenstadt. The house situated in a huge park (3000 square meters) with the address Armbrustergasse $33^{72}$ was built in 1894-1895 by Anton Engert

66 A travel diary in the Moravian Land Archive in Brno informs us about his journey through the Suez Canal to Dire-Dawa, about the number of the hunted animals and about his journey back to Venezia via Brindisi and Egypt (MZA, G169, c. 393, i. n. 245).

67 FLESAR, ref. 6, p. 532, $564 \mathrm{nn}$.

68 ANNO Neues Wiener Journal 18. 12. 1924, p. 10.

69 ANNO Wiener Salonblatt 21.9.1924, p. 3.

70 PASSOLUNGHI, ref. 1, p. 269.

71 COLLALTO, ref. 43, p. 348.

72 At the time of the construction the address was Wienerstrasse 49, but later Wienerstrasse was 
and offered all comfort and luxury. Heiligenstadt, a Viennese suburb, provided a calm and still quite rural environment, but it was also a place where the contemporary aristocracy used to have their summer residences: Villa Colllato with its dominant position must presumably have been quite representative. ${ }^{73}$

Fin de siècle with its "Grosses Sterben" series in which death came for Brahms (1897), Crown Prince Rudolf (1889) Johann Strauss (1899) Empress Elisabeth (1898) and others ${ }^{74}$ did not seem to touch Emanuel and Irma a lot. Their life remained private and they spent more time in Switzerland and Paris than in Vienna and the Moravian estates. Even the beginning of war in 1914-the old-Austria's Armageddon ${ }^{75}$ - did not touch them too much. Emanuel still oscillated between the extremes of lavish luxury and ample charities. During the War his castle in Brtnice served as a military hospital, at first for officers only, later for military personnel in general, and he kept supporting many charity organizations with his donations. However, in 1918 the Habsburgs were overthrown, and the times changed radically. The Collalto estates were suddenly found in a newly born Czechoslovakia, a state which shared the contemporary problems of the whole region, above all its multi-ethnic nature. ${ }^{76}$ Czechoslovakia abolished the titles of nobility in 1918 and a year later the debate about abrogation of the Family Wardship (fideicommissum) started. The massive land reform in 1919 made the nobles defend their private property and large-scale agriculture. ${ }^{77}$ It sequestered all estates over 250 hectares, the land was then redistributed and overseen by the State Land Office. When the reform started, the nobles created the Union of Czechoslovak Large Landowners (Svaz československých velkostatkárù), which was supposed to lobby against the reform and advise its members the best way to save as much property as possible.

If before the war Emanuel occupied himself with his Moravian estates only a little, now all the projects were stopped for good. The family sepulchre in Nové Sady was planned to be reconstructed ${ }^{78}$ but in the uncertain times of the young

divided in three different streets.

73 The ground plan of the villa, together with its drawing, were published in Der Architekt magazine in 1896 (ANNO Zeitungen, Der Architekt 1896, p. 12).

74 See BROOK-SHEPHERD, Gordon. The Austrians. A thousand-year Odyssey. New York: Carrol Graf Publishers, 2002, p. 123. ISBN 0786711027.

75 Ibidem, p. 150-168.

76 That is why Cornwall and Evans consider Czechoslovakia the best terrain for study of the nationalistic and later fascist Europe. According to them the First Czechoslovakian republic became a laboratory for the development of these problems (CORNWALL, Mark - EVANS, R. J. W. (eds.). Czechoslovakia in a Nationalist Europe 1818-1948. Oxford: Oxford University Press, 2007, p. 2. ISBN 9780197263914).

77 GLASSHEIM, Eagle. Fascist ideology among Bohemian Nobles 1880-1938. In CORNWALL - EVANS, Czechoslovakia in a Nationalist Europe 1818-1948, ref. 76, p. 27-43.

78 As the entry in the Flesar Chronicle for 1910 states (FLESAR, ref. 4, p 568). There were also 
Czechoslovakian Republic, no repairs even started. Building activities of Emanuel Collalto in Moravia had been modest anyway: a small chateau in Knežice had been adjusted to his needs ${ }^{79}$ because he liked gambling there surrounded by a circle of the closest people and friends. The chateau in Uherčice was newly furnished according to his taste. ${ }^{80} \mathrm{He}$ financially supported church restorations on his estates though none of them happened out of his intention. ${ }^{81}$ Brtnice Castle, the centre of the fideicommissum, reconstructed and rebuilt for the last time under his father Eduard, was not his favourite place to stay, before the First World War the husband of Emanuel's niece Max Kielmansegg with his family started living there so as to take care of the necessary administration. But after 1918 every plan for reconstruction had to be reconsidered carefully. As Eagle Glassheim has put it, for aristocrats the transition from empire to nation-state was particularly traumatic. Their national feelings were in question: they were not defined by a language, though, in Czechoslovakia aristocrats were treated as national antagonists. ${ }^{82}$

The most pressing problem was of course the land reform. In the former manors of Černá and Německý Rudolec, the evaluation process was finished in July 1923 and the Collalto lawyers JUDr. Janiczek and Dr. Dolansky acted as deputies for Prince Emanuel. But before the reform could limit all the other former manors, Prince Emanuel got into health troubles. The old problem with his digestive system, which he had been curing in the spa towns all around Europe, came again and suddenly Emanuel did not feel strong enough to administer his estates endangered by the reform. On top of that, the Family Wardship system (fideicommissum) was abrogated by Act No. 179/1924 on 3rd July 1924, which meant further problems for Emanuel's future heirs. Pressed by these problems and his own state of health, Emanuel finally decided to transfer his Czechoslovak majorate estates to his Italian cousin Manfred, under the condition of a high apanage for himself and his wife. Manfred set out on the journey from San Salvatore to Vienna, but Emanuel's disease was quicker. On 3rd December 1924, the day Manfred arrived, Emanuel was transported from his Heiligenstadt villa where he had been treated by Dr. Fink, to the Sanatorium Löw. ${ }^{83}$ Eight days later,

plans for a new decoration of the sepulchre from 1896 (MZA, G169, file 462, i. n. 511).

79 See MZA, G169, c. 388, i. n. 236, p. 23.

80 Marie Therese Collalto would later describe this furnishing as tasteless, similar to those of a waiting room in a rather small railway station (COLLALTO, ref. 43, p. 371-2).

81 For example, churches in Brtnice, Nové Sady, Okřřšky, Lubnice.

82 GLASSHEIM, Eagle. Noble nationalists. The transformation of the Bohemian Aristocracy. Cambridge MA: Harvard University Press, 2005, p. 81. ISBN 9780674018891.

83 The sanatorium located at Mariannengasse 20 was aimed mainly at prominent clients. Gustav Mahler died there in 1911. The building belongs today to Austrian Railways, but on its front facade, there is Mahler's memorial plaque. 
on 11th December 1924 at 5 pm Emanuel Josef 4th Prince Collalto e San Salvatore died of the consequences of the duodenal ulcer perforation and subsequent inner bleeding. ${ }^{84}$ The princely line of Eduard Collalto finished with him, thus the family branch of Eduard's brother Alfons was finally to get a word.

\section{Talented landowner with sense of art: Manfred Collalto}

Manfred Eduard 5th Prince Collalto e San Salvatore obtained the Moravian and Austrian possessions in the age of 54, therefore he was everything but an unexperienced youth. He was born on 18th January 1870 in the Viennese Am-Hof palace as the second son of the above-mentioned son of Eduard's brother: Octavian Salvator and his wife Princess Solms Hohensolms-Lich. At the age of 21 he married a year older Princess Thekla Ysenburg-Büdingen who gave him five children between 1902 and 1908, two sons: Octavian and Rambaldo and three daughters: Giselda, Anna and Polyxena. The whole family lived at Teschendorf in Mecklenburg, ${ }^{85}$ until 1911 when they moved to Staatz in Lower Austria: originally the possession of Manfred's mother. A year later Manfred's father died and his older brother Rambaldo died childless in December 1913, therefore the Italian estates with castle San Salvatore passed to Manfred's younger son Rambaldo (1908-1992). Unfortunately, when the First World War began, the exquisite ancient castle was badly damaged, and its following revival was fully Manfred's merit. ${ }^{86}$ There he proved his economic skills and artistic tastes for the first time. For his work on the castle reconstruction, Manfred was given Italian citizenship and great gratitude from the Susegana citizens ${ }^{87}$ after his death a memorial was erected in his honour to thank him for the reconstruction of the destroyed castle and village. ${ }^{88}$

Even though Manfred's older sister Marie Therese talks about the two princes as if they hardly knew each other, they kept meeting frequently during their summer stays in Uherčice; moreover, Emanuel stayed in touch with his Italian family branch and visited them in San Salvatore. Manfred was also Emanuel's groomsman in his wedding ceremony and sometimes the both men even travelled together: in one occasion also with Emanuel's step-brother Maurizio. ${ }^{89}$ Emanuel's

84 Matrikula, Sterbebuch 03-038, 1923-26, Wien 08, Alservorstadpfarre, fol. 104; for death notice see: HHStA SB Partezettelsammlung 16-51.

85 MZA, G 169 , c. 394, i. n. 259.

86 KAZLEPKA, ref. 10, p.175-177.

87 Susegana is the original village of San Salvatore in Treviso, Italy, situated under the castle itself.

88 MZA Brno, G169, c. 468, p. 241.

89 It was in summer 1900 to Hungary. (FLESAR, ref. 6, p. 542). 
death, however, meant a unification of the Italian and Austrian (at the moment already Czechoslovak) estates in hands of one owner once again. Aging Emanuel with his extravagant lifestyle and tendency to waste money without thinking had been a thorn in the family's side for long, therefore, there was no extensive mourning. Marie Therese comments Manfred's takeover of the Moravian estates by: Vaut mieux tard que jamais, ${ }^{90}$ and Manfred's old room attendant in Staatz congratulated his lord by saying Christkindl brought him quite a big present. ${ }^{91}$ However, the present turned out to be too big. Now, Manfred had to take care not only of the reconstruction of his Italian estates but also of the Moravian ones. The latter were not really neglected, though, after 62 years of Emanuel's rule, there was a lot to do about them. Waiver of the higher politics, high-society activities and a certain withdrawal of the head of the House of Collalto into his private life and simple maintenance of his Moravian estates was ended now. The 5th Prince of Collalto e San Salvatore definitely was not going to continue in the line followed by his eccentric old uncle. But Manfred came into a complicated situation and he had only a short time to solve it.

Emanuel's funeral took place in the Viennese church Zur Allerheiligen Dreifaltigkeit in Alserstrasse on 13th December 1924, he was not buried in the family sepulchre like his parents, but chose instead a simple grave at the Hietzing cemetery in Vienna. Then, his last will was to bring a lot of worries to Manfred. As a matter of fact, the whole inheritance procedure took 4 years due to the complications with Family Wardship abrogation in Czechoslovakia and was finished only in January 1928, but even at the time of Manfred's death in 1940 some estates were still registered on Emanuel's name. ${ }^{92}$ Unpopular Irma, now Princess-widow, did not present a big problem. She was left her husband's villa in Heiligenstadt, an annual widow rent of 100000 Czech crowns and a right to use certain rooms of Uherčice chateau. Even though it seemed as a royal apanage, in the financially uncertain situation of the first Austrian republic and due to problems with Czechoslovakian land reform, it was not royal enough. In 1928 she got in financial difficulties and had to sell her villa in Armbrustergasse 33 to Adolf Hahn, ${ }^{93}$ also her right to visit Uherčice seemed to collide with the new

90 Better late than never (COLLALTO, ref. 43, p. 345).

91 Ibidum, p. 348.

92 MZA Brno, F19, c. 359.

93 The auction catalogue offered the artworks and furnishing of the villa and consisted of 312 items. The auction itself was held between 4th and 5th June 1928 in Alfred Wawra Salon in Lothringerstrasse 14. See WAWRA, C. J. Versteigerung der Gemälde, Skulpturen, Möbel, Dekorationsgegenstände usw. aus dem Besitz der Frau Irma Collalto. Wien 1928. The villa was later sold to Adolf von Zsolnay, later it was used by Heimwehr and in 1945 it was destroyed by bombs. Nowadays Rudolf-Sarközy Hof occupies its place. (I am grateful for this information to the Döblinger Extrablatt editor, Mr. Wolfgang E. Schulze). 
owner's intentions. ${ }^{94}$ She died on 9th May 1931 of lung oedema combined with the heart insufficiency ${ }^{95}$ at Premreinergasse 15, Vienna.

In the meantime, the land reform in Czechoslovakia continued.${ }^{96}$ Redistribution of the nobility's have sounded very modern average citizen, transferred wefrom Germans to aristocrats to the of Manfred's big rate its impact estates, 3,743 which meant whole Collalto were expropriamanor of Písečpriated compleand Rudolec hectares of foto Prince Manwere allotted as parts of the and even the recomplexes were

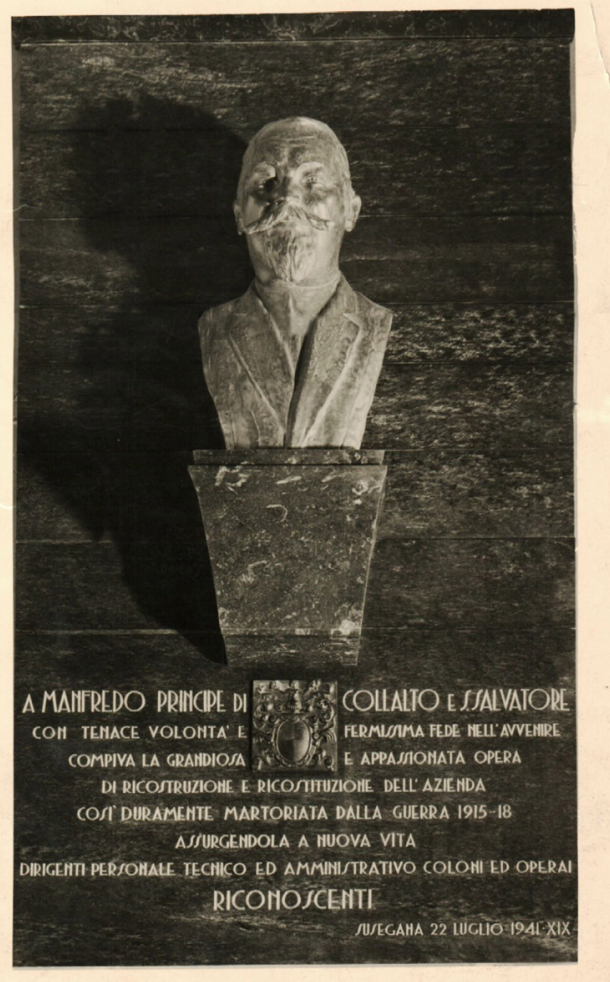
to problems with tration. ${ }^{98}$ Probabl where out of 6,501.98 ha of the total area, 5,401 ha was returned to Manfred

94 Marie Therese describes meeting Irma in Uherčice as an unpleasant family duty. The wedding of Polyxena Collalto and Alfred Josef Lichtenstein held on 23rd to 24th June 1928 in Uherčice presents the guestlist, where Irma's name is not included. Given her financial difficulties she must also have had problems with getting to Uherčice from Vienna.

95 Matrikula, Sterbebuch 13., Ober St. Veit 03-11, 1923-1934, fol. 447.

96 For more detailed information about the Czechoslovak land reforms in general see for example: HOMOLAC, Ludek - TOMSIK, Karel. Historical development of land ownership in the Czech Republic since the foundation of the Czechoslovakia until present. In Agricultural Economics/Zemédělská Ekonomika, 2016, Vol. 62 Issue 11, p. 528-536. ISSN ISSN 0139-570X.

97 HEIMANN, Mary. Czechoslovakia. The State that Failed. New Heaven: Yale University Press, 2011, p. 66. ISBN 978030017242.

98 MZA Brno, F19, c. 373 , i. n. 38. 
Collalto. Uherčice, located in the border area with a majority of German-speaking population was hit quite hard: out of 1606 ha only 306 ha of unconnected clusters were returned to Manfred.

Unlike Emanuel, Manfred was a suspicious man, which turned out to be a good characteristic in the situation of the young Czechoslovakia and the beginning of the Second World War. He liked strong cars - and owned three of them - and he knew what to do even in hopeless situations. In spite of the land-reform problems which started with his takeover of the Moravian family estates and finished only in mid 1930s Manfred turned out to be a good economist. Brtnice Castle, partly hit by fire in 1922 was reconstructed; after 1927, the small chateau in Kněžice was adapted for more permanent stay of Eduard Mensdorff-Pouilly and his wife: Manfred's oldest daughter Giselda. ${ }^{99}$ Manfred himself adapted Uherčice chateau for his frequent stays, in 1926 the roofs were changed ${ }^{100}$ and the chateau-chambers were equipped with new furniture and the artworks coming originally from the other Moravian Collalto residences. ${ }^{101}$ Nevertheless, the financial situation of the returned estates was not good at all. In 1936 Manfred had to sell his Lower-Austrian estates including Staatz and the monthly costs of Uherčice chateau of around 170000 Czechoslovak crowns became a burden for other estates after the land reform. Mainly Brtnice with its forest complexes had to pay for the economically passive Uherčice manor. ${ }^{102}$ But he also sought new financial resources. The brickyard in Okřišky was bought together with a new patent for the hollow bricks, the unprofitable clusters of woods were sold to the town of Jihlava and operation of breweries was increased.

It was during the time when the Second Czechoslovak Republic started and soon finished again (6. 10. 1938 - 13. 3. 1939), that Manfred's Uherčice became a part of the Sudetenland, while the rest of the estates including their centre at Brtnice were in the Protectorate. While Emanuel adopted the Czechoslovakian citizenship, Manfred remained an Italian citizen and so did his son, living in Brtnice Castle. No documents inform us about Manfred's relationship to the Third Reich, but whatever it was, Manfred became seriously ill in 1939 and died on 22nd July 1940 in Uherčice chateau at the age of 71 . He was buried 4 days later in Vratěnín (Frattig) cemetery. ${ }^{103}$

99 PLAČEK, Miroslav. Nejprve dvorec - nakonec pozdně renesanční dependencie. In Archeologia historica, 2017, 42, 2, p. 523-537. ISSN 0231-5823.

100 The master builder was Josef Klem from Třebíč. (MZA Brno, G169, c. 396, i. n. 261).

101 KAZLEPKA, ref. 10, p. 177.

102 Státní okresní archív (further on: SOkA) Jihlava, fund JNV - konfiskát Collalto, c. 5, i. n. 19, Národní pozemkový fond čj. 1827/46.

103 HHStA SB Partezettelsammlung 16-56. 


\section{Loss of the Moravian estates: Octavian Collalto}

Manfred's son Octavian became the universal heir to the Moravian possessions, but his short holding of them was to be only an epilogue: his inheritance became a Danaian gift. Octavian was born on 12th October 1906 in Teschendorf and at the time of his father's death he was 34. Before WW II., after the Kielmanseggs - Emanuel's former protégés - left to Atzgersdorf, Octavian and his wife Marie Camila née Windisch-Graetz used to spend their summertime in Brtnice.

His stays were not just recreational, Octavian administered the whole estate, which his father Uherčice, Italian trian estates - had himself. Octavian hunting dogs there parts of the castle He was in frequent siblings: the eldest visiting Octavian while her husband above-mentioned ky and her mother, lived with her in lot of letters writbrother Rambald and by younger Polyxena are prechildren also atJihlava, where a for them. ${ }^{105}$

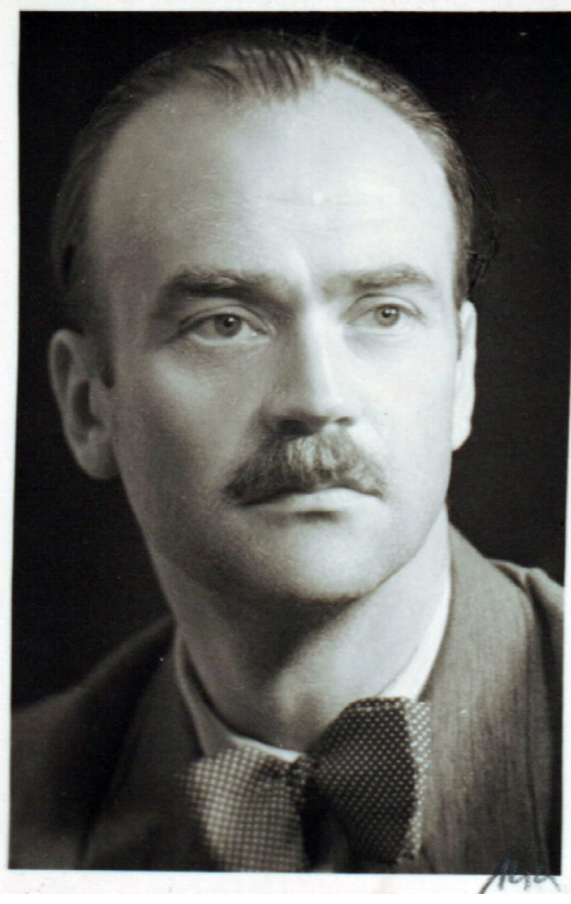

- busy with the and Lower-Auslittle time to handle kept his beloved and adapted some as his apartment. ${ }^{104}$ touch with other Giselda (Didi) was (Tadi) quite often took care of the brickyard in OkříšManfred's widow, Kněžice, also a ten by the younger (Rami) from Italy sisters Anna and served. Octavian's tended schools in house was rented

It changed radically with the beginning of the World War II. As Lothar Höbelt puts it, in the war situation the Collaltos recollected their origin in Italy and only rarely came to Brtnice to hunt. ${ }^{106}$ Even though Manfred had started with savings in the effort to make the estates economically sustainable, the curtailed Collato estates in Moravia would have become a problem in future. But no future came. As soon as the war ended, president Beneš talked in his mid-June speech in Tá-

104 SOkA Jihlava, OU Brtnice, inv. n. 19 Pamětní kniha městyse Brtnice, (Memory book of the town of Brtnice), p. 199.

105 In Roseggergasse 13, (today Svatopluka Čecha): MZA Brno, F19, c. 391, i. n. 200.

106 HÖBELT, Lothar. Die mährische Aristokratie in der ersten Hälfte des 20. Jahrhunderts. In KNOZ, Tomáš - DVOŘÁK, Jan (eds.). Šlechta v proměnách věků. Brno: Matice moravská, 2011, p. 245-252. ISBN 9788086488714. 
bor about "getting rid of the Germans forever", 107 and on 21 st June a presidential decree was issued, in which the "Speedy confiscation and redistribution of the land formerly belonging to Germans, Hungarians, traitors and enemies of the Czech and Slovak nation" 108 was announced. Octavian's possession was originally confiscated as a German estate on the grounds of the decree of Regional National Committee (ONV) in Jihlava issued on 11. 7. 1945. Octavian objected to it, with the reference to his Italian nationality. That was the evident truth, but the anti-aristocratic situation in the post-war Czechoslovakia was favourable to no truth of that kind. In Puklice, the estate bordering with Brtnice in the Northeast, even a possession of a Czech Jew who died in Auschwitz was confiscated under the pretence of his treachery during the WW II, ${ }^{109}$ therefore it would have been silly to expect anything less for the Italian aristocrat. The Land National Committee (ZNV) in Brno found Octavian's objection legally right, therefore the reason was changed accordingly: Octavian Collalto was a traitor of the Czech nation owing to his sympathy for fascist policy in Italy, owing to his usage of German as a language of communication and last but not least owing to his help to German occupants against Czechs. ${ }^{110}$ 20th February 1946 a new confiscation Act No. A- 368/46- X was issued. Octavian appealed against it, his employees wrote and signed a statement testifying his help to partisans and Czech families during the war, but nothing could change the situation. ${ }^{111}$ Octavian's appeal was dismissed on 10th October 1946. The following process of nationalization could be a subject of a similar text of the same length. Octavian Collalto moved to San Salvatore, where he died on 13th October 1973.

\section{Conclusion}

While the fate of Octavian Collalto after the World War II was hardly exceptional, the stagnation of the family under the last four Collaltos mentioned in the introduction was not necessary. While after the loss of the patrimonial rights and the change from Lords to mere landowners the other noble Houses used their newly found incomes for industrial entrepreneurship, the Collaltos did not. However, as visible from the previous, their stagnation differed under each of the last estate holders. While Eduard still had some political activities, no matter

107 HEIMANN, ref. 95, p. 158.

108 Decree No. 12/1945.

109 KOUMAR, Jan. Konfiskace majetku českých Židů v poválečném Československu na př́kladu zámku a velkostatku Puklice (Confiscation of the property of Czech Jews in post-war Czechoslovakia following the example of the chateau and estate at Puklice). In Historická sociologie, 2018, 2. ISSN 1804-0616.

110 SOkA Jihlava, Fund JNV - konfiskát Collalto, i. n. 19, c. 5.

111 MZA Brno, G169, c. 138, i. n. 398. 
how sparse they were, and only his early death prevented him from wider political participation, Emanuel's withdrawal from higher politics and his shift to the dazzling high-class life was fully his intention. Manfred would have been a big figure in the history of the Moravian estates if it were not for the political situation of young Czechoslovakia, its land reform and the subsequent necessity to provide for the remaining land and its economy. Finally, Octavian had too little time to show what he could do, due to the Second World War and following expropriation of the remaining Collalto estates in Czechoslovakia. It is ironic that while Eduard can be still remembered in connection with the last reconstruction of Brtnice castle and Emanuel's building activity in Vienna is still provable by his new palace at Rathausstrasse, the estate-administration of economically talented Manfred brought no visible signs either to Moravia or to Vienna. While his merit in revival of the Italian San Salvatore is indisputable, Moravia has no reason to remember him vividly. Even his son's name is more often mentioned, since he was the last family member who owned the remnant of the Moravian possessions. The presence of the old Italian family in Moravia finished with Octavian, who moved back to San Salvatore, governed by his younger brother Rambald, who died in San Salvatore in the age of 82 in 1994. As was mentioned before, Octavian himself died in the age of 67. His son Manfred, born in 1932 in Vienna turned out to be the last male member of the House of Collalto. Nowadays, only Manfred's daughters are alive, and the family name is connected with the related House of Crö̈: Croÿ-Collalto.

The former Collalto estates in Moravia were highly neglected by the Czechoslovak state after 1945. Uherčice became a camp for female prostitutes and later it was used by the army which brought the whole chateau almost to the threshold of a complete destruction. The chateau has been slowly reconstructed recently and it is partly opened to visitors. The huge castle complex at Brtnice fell into disrepair and its present horrifying state can stand as a testimony to the lengthy legal property disputes in the Czech Republic after 1989. The little chateau in Černá became a worldwide famous BDSM facility resort known as Other World Kingdom after 1996 and brought a lot of problems and shame to the little village and its inhabitants. Nowadays the worldwide clients eager for the BDSM experience do not come anymore and the chateau is for sale. Due to highly likely legal complications after 1989 Octavian's legal heirs chose not to apply for the restitution of their former estates.

\section{* Picture Appendix:}

Picture 1: Atelier Rudolf Krziwanek in Vienna, Emanuel Collalto e San Salvatore around 1900. (MZA Brno, G 169, c. 467, f. 24), p. 643.

Picture 2: Memorial to Manfred Collalto in Susegana built in gratitude for restoration of San Salvatore. (MZA Brno, G169, c. 468, f. 24), p. 652.

Picture 3: Octavian Collalto, summer 1940. (MZA Brno, G169, c. 467, f. 199), p. 654. 


\section{DIE LETZTE MÄHRISCHEN FÜRSTEN AUS DEM HAUSE COLLALTO E SAN SALVATORE}

\section{JAN K O U M A R}

Dieser Artikel beschäftigt sich ausführlich mit den vier letzten Fürsten aus dem Hause Collalto. Zuerst bietet er einen selektiven Überblick über die Geschichte des Hauses: seine italienische Herkunft und der Erwerb des mährischen Eigentums (zehntgrößtes Fideikommiss in Mähren). Anschließend konzentriert sich der Artikel auf die vier letzten Mitglieder der Collalto Familie, die mit Mähren in Verbindung stehen: Eduard, dritter Fürst von Collalto (1810-1862), seiner Sohn Emanuel, vierter Fürst (1854-1924), Manfred, fünfter Fürst (1870-1940), und Octavian (1906-1973). Unter Ihnen stagnierte der Besitz der Familie weitgehend, obwohl die Ursache bei jedem ein bisschen unterschiedlich waren.

Eduard widmete sich nur begrenzt der österreichischen Politik: er war wirklicher Kämmerer und erbliches Mitglied des österreichischen Herrenhauses. Sein Leben war stark beeinflusst von einer erfolglosen Ehe, aus der ständig in Liebesaffären flüchtete und im Alter von 52 Jahren starb. Sein Sohn Emanuel war zur Zeit seines Todes nur 8 Jahre alt und die Erziehung seiner Mutter machte ihn zu einer der selbstlosesten Figuren in der Familiengeschichte, gleichzeitig legte sie jedoch den Grundstein für seine Neigung zur Halbwelt. Er heiratete eine Frau bürgerlichen Ursprungs, Irma Büttner, zog sich aus der Politik zurück und führte das großartige Leben eines Aristokraten der Oberklasse.

Nach dem Ersten Weltkrieg war das Eigentum der Collaltos plötzlich Teil der neu gegründeten Tschechoslowakischen Republik und wurde von einer massive Landreform bedroht. Darüber hinaus wurde das Institut für Fideikommiss ebenfalls abgeschafft. All diese Probleme trafen Emanuel im Alter von 70 Jahren und bei schlechter Gesundheit und er starb am 11. Dezember 1924 ohne sie zu lösen.

Sein Nachfolger, der 54-jährige Manfred, war ein talentierter Landbesitzer und wäre vielleicht ein guter Verwalter des Mährischen Besitzes geworden aber die Landreform traf die ehemaligen Güter hart: ein Drittel der Ländereien der Collalto Familie wurde enteignet und die finanzielle Situation der zurückgegebenen Grundstücke war sehr schlecht. Manfred konnte jedoch nicht viel dagegen tun, da er am 22. Juli 1940 im Alter von 71 Jahren verstarb.

Manfreds Sohn Octavian wurde während der unsicheren Zeit des Zweiten Weltkrieges sein Gesamterbe und diese Unsicherheit würde zu seinem Verhängnis. Im Jahre 1945 wurden alle seine Ländereien aufgrund falscher Vorwürfe der Germanisierung und des Verrats an der tschechischen Nation beschlagnahmt. Octavian und seine Familie zogen auf die italienischen Bauernhöfe in San Salvatore, wo er später im Alter von 67 Jahren starb.

Mgr. Jan Koumar

Univerzita Karlova, Fakulta humanitních studií

U Kř́žze 8, Praha 5 - Jinonice

e-mail: jan.koumar@gmail.com 